УДК 553.612-553.623

\title{
МАМОНСКАЯ ТОЛЩА - ИСТОЧНИК ПОЛУЧЕНИЯ СТЕКОЛЬНОГО, ФОРМОВОЧНОГО И СТРОИТЕЛЬНОГО ПЕСЧАНОГО СЫРЬЯ, ОБОГАЩЕННОГО КАОЛИНА
}

\author{
С. В. Мануковский, А. В. Крайнов, Н. А. Корабельников, А. В. Милаш \\ Воронежский государственный университет
}

Поступила в редакцию 27 февраля 2018 г.

\begin{abstract}
Аннотация: мамонская песчано-каолиновая толща (ПКТ) позднедевонского возраста, развитая в южной (присводовой) части Воронежской антеклизы, обычно рассматривалась как источник для получения каолина. Однако песчаная часть разреза превалирует над её глинистой составляющей. В песках присутствует глинистая примесь, извлекаемая при гидрочиклонном обогащении. Проведенные исследования показали, что в песчаных отложениях мамонской толщи сосредоточено стекольное, формовочное, строительное сырьё. При наличии глинистой примеси из неё можно получать обогащенный каолин. Подсчитанные суммарные авторские запасы по категории $C_{1}+C_{2}$ по пескам составляют более 20 млн. $m$, по каолинам - более 11 млн. т. В том числе 1,5 млн. $m$ приходится на обогащенный каолин из песков. Неглубокозалегающая толща позволяет разрабатыввать её открытым способом, в случаях большой мощности вскрыши - гидроскважсинным.

Ключевые слова: пески, вторичные каолины, акиессорные минералы, оксиды железа, мамонская толща.

\section{MAMMON DEPOSITS - SOURCE OF PRODUCTION OF GLASS, MOLDING AND CONSTRUCTION RAW MATERIAL, ENRICHED KAOLIN}

Abstract: Mamon sand-kaolinic stratum (SKS) of the upper Devonian age, developed in the southern part of the Voronezh anteclise, was usually considered as a source for the production of kaolin. However, the sandy part of the section prevails over its clayey component. Often in the sands there is a clayey impurity that is easily recovered by hydroclassification. The carried out researches have shown, that in sandy adjournment of the mamonian stratum is concentrated glass, forming, building raw materials. In the presence of a clayey admixture, it is possible to obtain enriched kaolin from it. The estimated total inventories in the $C_{1}+C_{2}$ category for sands are more than 20 million tons, for kaolins - more than 11 million tons. Including 1,5 million tons is accounted for enriched kaolin from the sands. With a shallow occurrence of the strata, it can be developed by the open method, in cases of high stripping capacity - by a hydro-well.
\end{abstract}

Keywords: sands, secondary kaolins, accessory minerals, iron oxides, Mammon deposits.

Мамонская песчано-каолиновая толща выполняет эрозионно-тектоническую депрессию (ЭТД) в южной части ЦЧР [1] и протягивается от г. Нового Оскола до границ Воронежской и Волгоградской областей в виде полосы шириной от 40 до 60 км, увеличивающейся до 100 км на крайнем востоке своего распространения (рис. 1).

В структурном отношении ЭТД приурочена к своду и юго-восточному склону Воронежской антеклизы. ПКТ с размывом залегает на породах кристаллического фундамента докембрия и девона, а перекрывается разновозрастными осадочными отложениями мела и квартера, на самом юге - доломитизированными из- вестняками озерско-хованской толщи верхов фамена $[2,3]$. Её кровля обычно залегает на глубинах от первых метров в современных речных долинах до 200 м на водоразделах.

Начиная с 60-х годов прошлого столетия, мамонская толща рассматривалась как полигон для поисков месторождений каолинов. Различными организациями проводились поисково-разведочные работы, выделялись перспективные участки, которые разбуривались разными количествами скважин, но месторождений каолинов не выявлено. При этом подсчитывались прогнозные запасы каолинов в десятки миллионов тонн. В качестве попутно-добываемого 


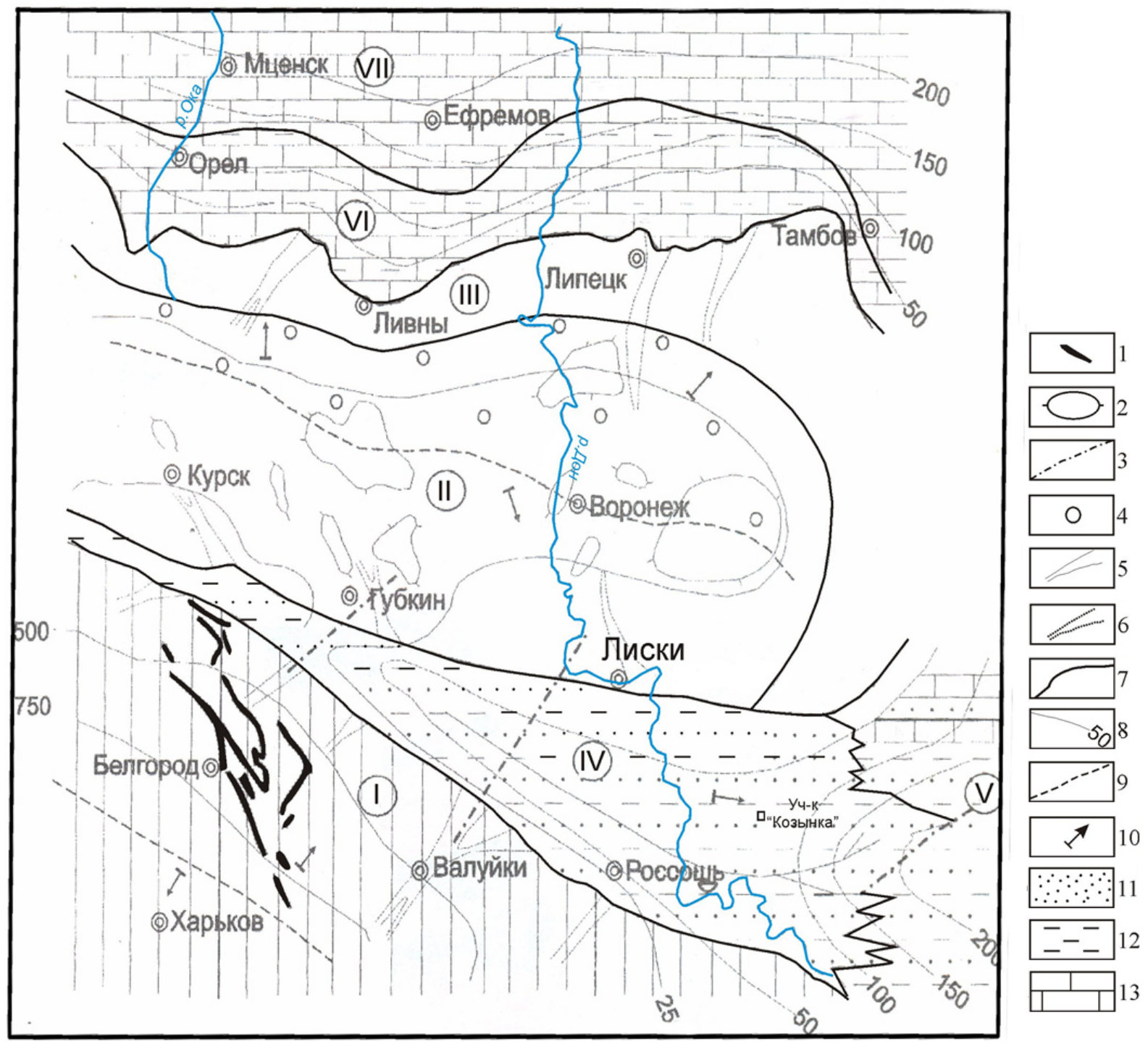

Puc. 1. Схематическая литолого-палеогеоморфологическая карта позднефранского-среднефаменского времени на территории Воронежской антеклизы [2]. Морфогенезис рельефа (римскими цифрами): $I$ - пенеплен слаборасчлененный; равнины: $I I$ - эрозионно-денудационная, $I I I$ - прибрежно-морская денудационно-аккумулятивная, $I V$ - аллювиальная, $V$ - дельтоволагунная, VI - прибрежно-морская, VII - мелководно-морская; Элементы рельефа: 1 - гряды и останцы литологоструктурные, 2 - поднятия, 3 - разломы, 4 - карстовые полости; долины речные: 5 - установленные, 6 - предполагаемые, 7 границы распространения равнин, 8 - изопахиты позднефранских-фаменских отложений, 9 - линия водораздела, 10 направление сноса; породы: 11 - пески, алевриты, 12 - глины, 13 - карбонатные породы, 14 - зоны мамонской толщи: 3 западная, $Ц$ - центральная, $B$ - восточная.

В работе [2] выделены прогнозные участки для постановки поисково-разведочных работ на каолины (4 участка) и кварцевые пески (6 участков). Постепенно пришло осознание того, что кварцевые пески сами по себе или попутно добываемые, представляют не менее ценное, чем каолины, полезное ископаемое как стекольное, формовочное и строительное сырьё. Вместе с тем каолинитсодержащие разности песков могут служить источником получения обогащенного каолина. Поэтому в настоящей статье основное внимание уделено характеристике обломочной составляющей мамонской толщи.

Изучение ПКТ показало, что её мощности варьируют в широких пределах и зависят от местонахожде- ния в ЭТД, морфологии подошвы толщи и интенсивности постдевонских размывов. Наибольшие значения мощности приходятся на центральную часть эрозионно-тектонической депрессии и на врезы долин предмамонского рельефа. Они возрастают по направлению на восток и юго-восток по склонам антеклизы и уменьшаются к краям ЭТД вплоть до нулевых значений. Мощности ПКТ заметно падают в результате неоген-четвертичных размывов, когда были заложены современные речные долины. В некоторых местах этих долин (реки Дон, Тулучеевка) породы мамонской толщи выходят на дневную поверхность. В среднем мощности ПКТ составляют десятки метров, увеличиваясь вниз по склонам до 200 м (рис. 2). 


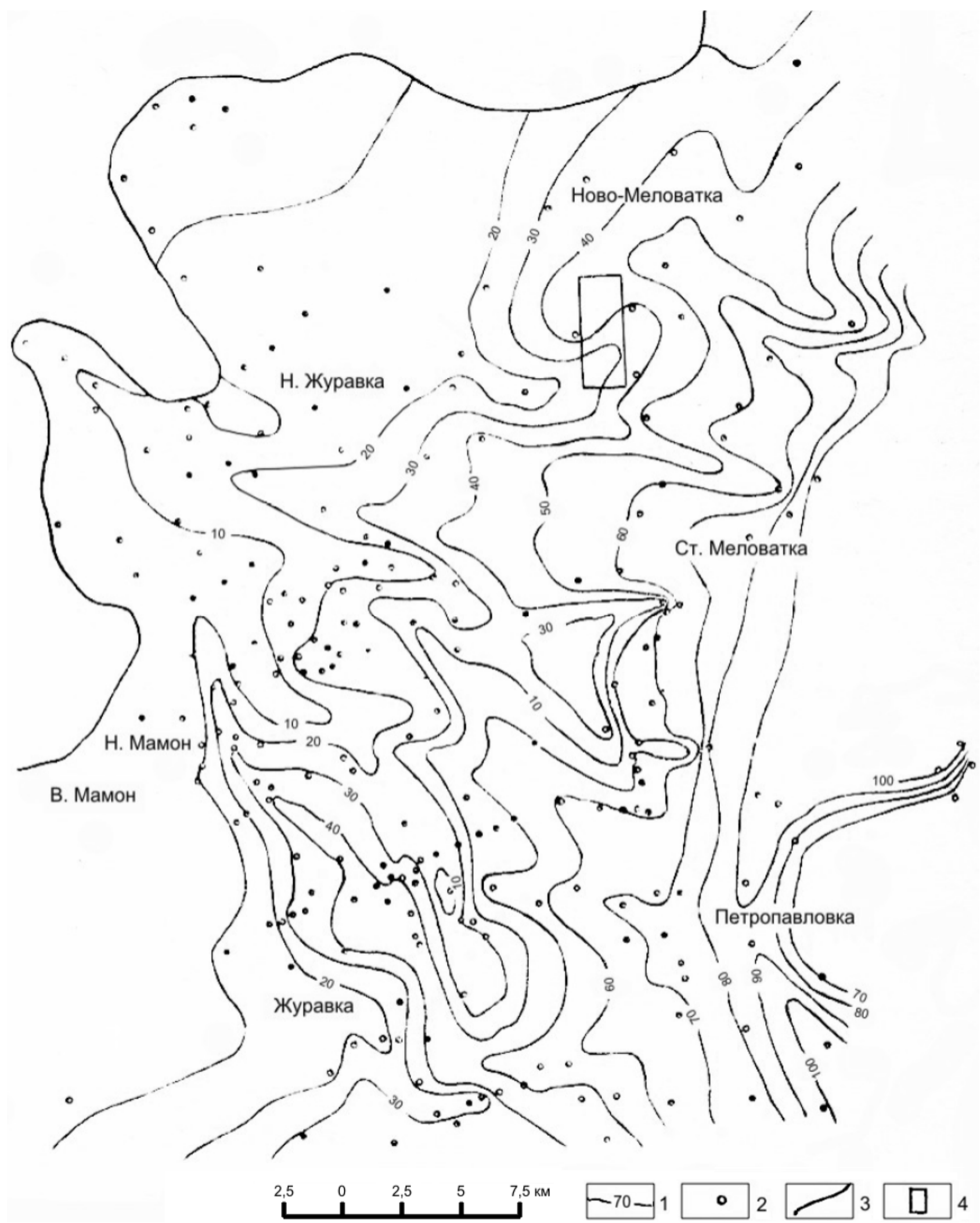

Puc. 2. Карта изопахит мамонской толщи (юго-восточный склон Воронежской антеклизы) [2]: 1 - изопахиты отложений мамонской толщи; 2 - скважины; 3 - границы размыва отложений мамонской толщи; 4 - границы Новомеловатского участка.

ПКТ представлена делювиально-пролювиальноаллювиальными отложениями, которые восточнее линии Мигулинская - Новохоперск, сменяются морскими образованиями. Переход песчано-каолиновой 60 толщи в нормально-морские отложения осуществлялся через лагунные фации, близкие по составу к аллювиальным, но отличающиеся от них мелкозернистостью, лучшей сортировкой, наличием тонкоотмучен- 
ных глин и горизонтальной слоистостью.

Среди кварцево-каолиновых пород появляются известняки, количество которых быстро нарастает к востоку и северу. Одновременно происходит выклинивание песков и алевритов, что приводит к преобладанию в терригенной части разреза глин. Формирование пород мамонской произошло преимущественно за счет размыва кор выветривания на кристаллических породах докембрия [4].

Для мамонской толщи характерно переслаивание кварцевых разнозернистых песков, в том числе каолинистых, и в различной степени алевритистых, в нижней части разреза ожелезненных, иногда гумусированных глин, практически нацело состоящих из каолинита. Подчиненное значение в разрезе занимают каолинистые алевриты и песчаники с кварцево-каолиновым цементом. Пески слагают основную часть разреза, а мощность их пластов достигает 20 и более метров.

Пески, преимущественно, плохо сортированы, от тонких до грубых, с включениями гравия и гальки кварца. Они относятся к аллювиальным русловым или к нерасчлененным делювиально-пролювиальным и аллювиальным фациям. В русловых аллювиальных фациях накапливались пески (с линзами песчаников) серые, кварцевые, крупно- и грубозернистые, косо-, реже неяснослоистые. Пески отсортированы, с невысоким содержанием пелитовых фракций; гравийные, прослоями переходящие в гравелиты, с хорошо и угловато окатанной галькой дымчатого, реже - водянопрозрачного кварца. Нерасчлененные делювиальнопролювиальные и аллювиальные русловые отложения представлены песками плохо сортированными, кварцевыми, разнозернистыми, от мелко- до грубозернистых, алевритовыми, сильно глинистыми, до песчанистых глин. Количество гравия колеблется от десятых долей до $20 \%$. В толще несортированных песков, отмечаются прослои (от нескольких сантиметров до нескольких дециметров) песков с косой однонаправленной слоистостью; однородных, хорошо сортированных, преимущественно крупнозернистых.

Наиболее перспективными для поисков месторождений, как каолинов, так и песчаного сырья в ПКТ являются площади на территории между населенными пунктами Н. Мамон и Калач. Они приурочены к участкам долин левых притоков р. Дон с минимальной мощностью вскрыши. Там неглубоко залегающая мамонская толща представлена континентальным комплексом пролювиально-делювиальных, аллювиальных и озерно-болотных образований, и отмечаются относительно мощные пласты каолинитсодержащих песков и глин. По три участка каолинов приурочены к долинам рек Тулучеевка и Козынка, один - к р. Мамоновка. Участки по р. Тулучеевке находятся: Петропавловский - в 30-42 км к югу от участка «Козынка»; Красноселовский - в 18-27 км к югу; Ширяево - в 12 км к юго-востоку. Нижнемамоновский участок расположен в 28-30 км югозападнее участка «Козынка» в долине р. Мамоновка. К долине р. Козынка приурочены участки Репьяхов- ский (в 19-25 км к северу-северо-востоку от участка «Козынка»), Меловатка (в 5-9 км к югу-юго-востоку) и Морозовский.

Последний в центральной и северной своих частях пространственно совпадает с участком «Козынка», разведанном в 2015-2017 гг ООО «Акма-Универсал» по договору с ООО «КварцГрупп». На участке «Козынка» выявлено 7 горизонтов полезных ископаемых, связанных с ПКТ. Полезная толща представлена чередованием кварцевых разнозернистых каолинизированных песков и линз каолинитовых глин различной мощности (от 1-2 см до 6-8 м). В разрезе снизу верх выделяются (рис. 3) следующие слои (горизонты) полезных ископаемых и, соответственно, номера и категории блоков: I - слой кварцевых каолинитсодержащих песков (блоки $\mathrm{C}_{1}$-I, $\mathrm{C}_{2}-\mathrm{I}$ ); II - пласт каолинитовых глин (блоки $\mathrm{C}_{1}$-II, $\mathrm{C}_{2}$-II); III - слой кварцевых каолинитсодержащих песков (блоки $\mathrm{C}_{1}$-III, $\mathrm{C}_{2}$-III); IV - слой каолинитовых глин (блоки $\left.\mathrm{C}_{1}-\mathrm{IV}, \mathrm{C}_{2}-\mathrm{IV}\right) ; \mathrm{V}$ - слой кварцевых каолинитсодержащих песков (блоки $\mathrm{C}_{1}-\mathrm{V}$, $\mathrm{C}_{2}-\mathrm{V}$ ); VI - слой каолинитовых глин (блоки $\mathrm{C}_{1}-\mathrm{VI}, \mathrm{C}_{2}$ $\mathrm{VI}$; VII - слой кварцевых каолинитсодержащих песков (блоки $\mathrm{C}_{1}$-VII, $\mathrm{C}_{2}$-VII).

Отмеченные тела полезных ископаемых относительно выдержаны по простиранию и прослеживаются на оценочной площади, они увязываются на территории, изученной как по категории $\mathrm{C}_{1}$, так и $\mathrm{C}_{2}$ (таблица 1). Нижние горизонты (I, II, III) распространены на всей оценочной площади, верхние (IV, V, VI, VII) не везде за счет сокращения их мощности или выклинивания в разрезах некоторых скважин. Наименьшую площадь распространения из всех слоев имеет верхний глинистый слой.

На участке «Козынка» среди вскрытых тел полезных ископаемых наибольшая мощность отмечается для нижних горизонтов. Так, средняя мощность слоя I кварцевых каолинитсодержащих песков 5,36-5,60 м. В вышележащих кварцевых песках их средняя мощность уменьшается: в III слое - 3,18-3,38 м; в V 1,43-1,87 м; и в VII - 1,17-1,71 м. Такая же тенденция прослеживается и для глин. Средние мощности слоёв каолинитовых глин II - 4,36, IV - 1,36 м, VI - 0, 9 м.

В 4-х горизонтах кварцевых каолинитсодержащих песков основным полезным ископаемым являются кварцевые пески для стекольной промышленности, попутным компонентом - каолин обогащенный (фракция < 63 мкм) из их глинистой составляющей [5]. По содержанию основных оксидов $\left(\mathrm{SiO}_{2}, \mathrm{Fe}_{2} \mathrm{O}_{3}\right.$, $\mathrm{Al}_{2} \mathrm{O}_{3}$ ), регламентирующих марку стекольных песков [6], можно выделить две группы песчаных горизонтов. Первая - это верхние горизонты VII и V, в блоках которых их средневзвешенное содержание $\left(\mathrm{SiO}_{2}-\right.$ 98,41-98,80\%; $\mathrm{Al}_{2} \mathrm{O}_{3}-0,48-0,64 \% ; \mathrm{Fe}_{2} \mathrm{O}_{3}-0,20-0,25$ $\%)$ определяет низкие марки пониженной светопрозрачности - ПС-250. Вторая группа - нижние горизонты III, I, в блоках которых пески более чистые $\left(\mathrm{SiO}_{2}-98,79-98,97 \% ; \mathrm{Al}_{2} \mathrm{O}_{3}-0,44-0,61 \% ; \mathrm{Fe}_{2} \mathrm{O}_{3}-\right.$ 0,14-0,15\%), что повышает их ценность до марок полубелых - ПБ-150-2 и ПБ-150-1. 


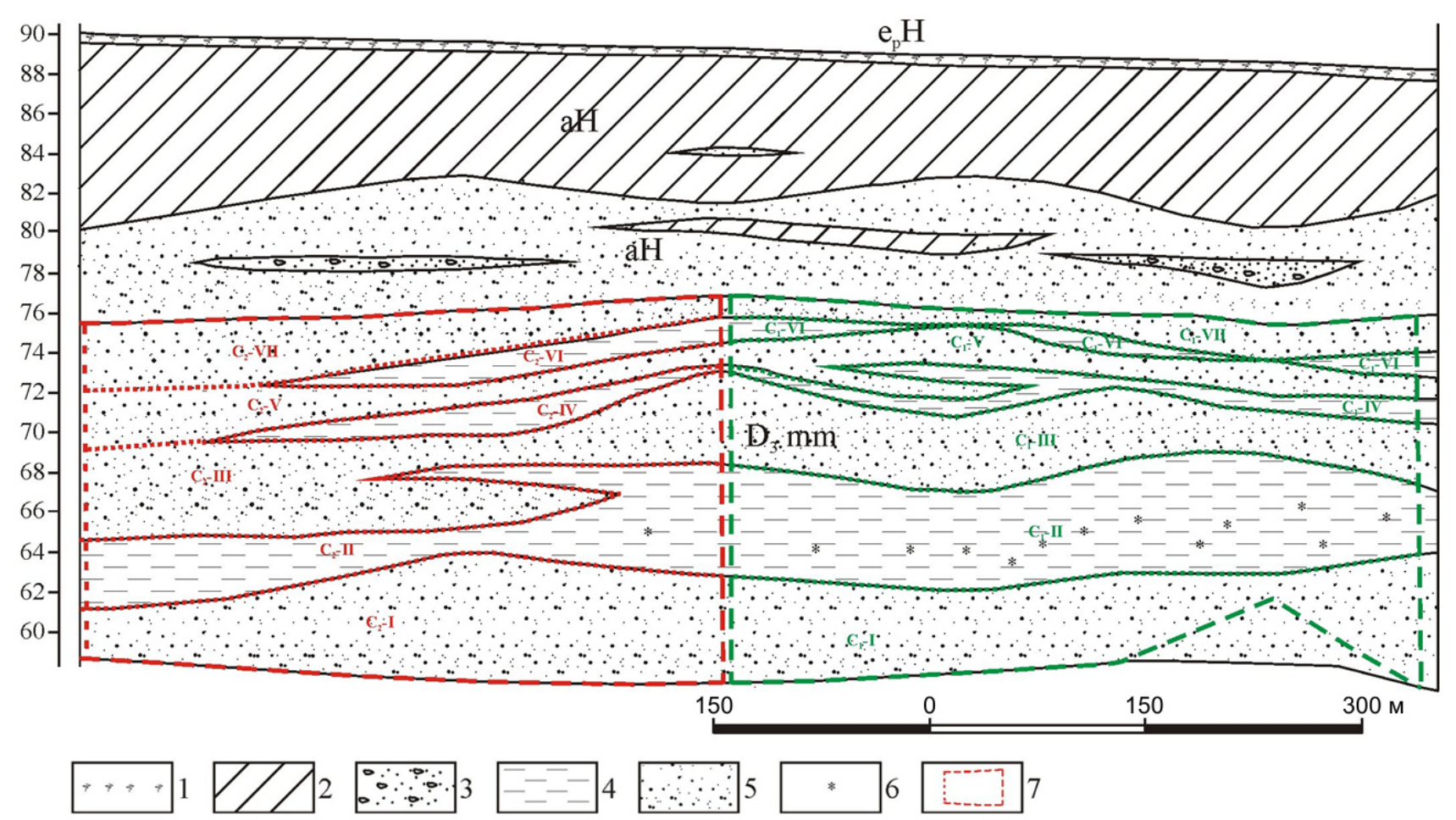

Puc. 3. Разрез участка «Козынка»: 1 - почвенно-растительный слой, 2 - суглинок, 3 - песок разнозернистый с гравием, 4 - глина, 5 - песок, 6 - ожелезнение, 7 - контуры подсчетов запасов.

Таблица 1

Сводная таблица характеристики тел полезных ископаемых (морфологии, качества, авторских запасов и ресурсов)

\begin{tabular}{|c|c|c|c|c|c|c|c|c|c|c|}
\hline \multirow{2}{*}{$\begin{array}{l}\text { Номер } \\
\text { п|п }\end{array}$} & \multirow{2}{*}{$\begin{array}{c}\text { Наименование } \\
\text { блоков* }\end{array}$} & \multirow{2}{*}{$\begin{array}{c}\text { Средняя } \\
\text { мощность } \\
\text { ПИ в бло- } \\
\text { ке, м }\end{array}$} & \multicolumn{2}{|c|}{$\begin{array}{c}\text { Запасы основного полезного } \\
\text { ископаемого в блоке, т }\end{array}$} & \multirow{2}{*}{$\begin{array}{c}\text { Фракция } \\
<63 \text { мкм, } \\
\%\end{array}$} & \multicolumn{3}{|c|}{$\begin{array}{c}\text { Содержание основных } \\
\text { оксидов в каолине (во } \\
\text { фракции <63мкм), \% }\end{array}$} & \multicolumn{2}{|c|}{$\begin{array}{c}\text { Запасы } \\
\text { каолина, т }\end{array}$} \\
\hline & & & $\begin{array}{c}\text { Пески кварцевые, } \\
\text { каолинсодержащие }\end{array}$ & Каолины & & $\mathrm{Al}_{2} \mathrm{O}_{3}$ & $\mathrm{Fe}_{2} \mathrm{O}_{3}$ & $\mathrm{TiO}_{2}$ & $\begin{array}{c}\text { в } \\
\text { песках }\end{array}$ & общие \\
\hline 1 & $\mathrm{C}_{1}-\mathrm{I}(\mathrm{a})$ & 5,36 & 2429907 & - & 4,81 & 34,12 & 1,86 & 1,13 & 116880 & \\
\hline 2 & $\mathrm{C}_{1}-\mathrm{II}$ (б) & 4,69 & - & 2055049 & 84,27 & 30,16 & 4,39 & 1,42 & - & \\
\hline 3 & $\mathrm{C}_{1}-\mathrm{III}(\mathrm{a})$ & 3,18 & 1430925 & - & 8,74 & 33,45 & 1,55 & 1,12 & 125109 & \\
\hline 4 & $\mathrm{C}_{1}-\mathrm{IV}$ (б) & 1,41 & - & 561489 & 80,86 & 31.81 & 1,79 & 1,45 & - & \\
\hline 5 & $C_{1}-V(a)$ & 1,43 & 638698 & - & 8,33 & 32,15 & 1,70 & 1,15 & 53186 & \\
\hline 6 & $\mathrm{C}_{1}-\mathrm{VI}$ (б) & 0,89 & - & 340638 & 81,37 & 31,82 & 2,15 & 1,43 & - & \\
\hline 7 & $\mathrm{C}_{1}-\mathrm{VII}$ (a) & 1,17 & 502401 & - & 12,41 & 32,50 & 1,94 & 1,04 & 62352 & \\
\hline \multicolumn{3}{|c|}{ ИТОГО по категории $\mathrm{C}_{1}$ : } & 5001931 & $\begin{array}{c}2957 \\
176\end{array}$ & & & & & $\begin{array}{l}\mathbf{3 5 7} \\
\mathbf{5 2 7}\end{array}$ & $\begin{array}{c}3314 \\
703 \\
\end{array}$ \\
\hline 1 & $\mathrm{C}_{2}-\mathrm{I}(\mathrm{a})$ & 5,60 & 7064944 & - & 4,25 & 34,20 & 1,77 & 1,18 & $\begin{array}{l}300 \\
044\end{array}$ & \\
\hline 2 & $\mathrm{C}_{2}-\mathrm{II}$ (б) & 4,04 & - & $\begin{array}{c}4932 \\
015\end{array}$ & 84,43 & 30,39 & 4,21 & 1,42 & - & \\
\hline 3 & $\mathrm{C}_{2}-\mathrm{III}$ (a) & 3,38 & 4228693 & - & 9,25 & 33,79 & 1,62 & 1,07 & 391091 & \\
\hline 4 & $\mathrm{C}_{2}-\mathrm{IV}$ (б) & 1,32 & - & $\begin{array}{c}1419 \\
212\end{array}$ & 80,68 & 32,44 & 1,57 & 1,42 & - & \\
\hline 5 & $C_{2}-V$ (a) & 1,87 & 2332063 & - & 9,11 & 34,32 & 1,49 & 0,97 & 212537 & \\
\hline 6 & $\mathrm{C}_{2}-\mathrm{VI}$ (б) & 0,92 & - & 846546 & 80,41 & 32,41 & 1,96 & 1,44 & - & \\
\hline 7 & $\mathrm{C}_{2}-\mathrm{VII}$ (a) & 1,71 & 2127026 & - & 15,61 & 33,33 & 1,81 & 0,98 & 332127 & \\
\hline \multicolumn{3}{|c|}{ ИТОГО по категории $\mathrm{C}_{2}$ : } & 15752726 & $\begin{array}{c}7197 \\
773\end{array}$ & & & & & $\begin{array}{c}1235 \\
799\end{array}$ & $\begin{array}{c}\mathbf{8 4 3 3} \\
572 \\
\end{array}$ \\
\hline \multicolumn{3}{|c|}{ ВСЕГО по категориям $\mathrm{C}_{1}+\mathrm{C}_{2}$ : } & 20754657 & $\begin{array}{c}10154 \\
949\end{array}$ & & & & & $\begin{array}{c}1593 \\
326\end{array}$ & $\begin{array}{c}11748 \\
275\end{array}$ \\
\hline \multicolumn{11}{|c|}{ Ресурсы категории $\mathbf{P}_{\mathbf{1}}$ и характеристика качества полезного ископаемого } \\
\hline \multirow{2}{*}{1} & \multirow{2}{*}{$P_{1}-I(a, \sigma)$} & 14,46 & 37012034 & - & 7,76 & 33,38 & 1,77 & 0,94 & $\begin{array}{c}2873 \\
907\end{array}$ & \\
\hline & & 3,47 & - & $\begin{array}{c}8633 \\
984\end{array}$ & 85,36 & 31,14 & 3,11 & 1,46 & - & \\
\hline \multicolumn{3}{|c|}{ ИТОГО по категории $\mathbf{P}_{1}:$} & 37012034 & $\begin{array}{c}8633 \\
984\end{array}$ & & & & & $\begin{array}{c}2873 \\
907\end{array}$ & $\begin{array}{c}11507 \\
891\end{array}$ \\
\hline
\end{tabular}

* Полезное ископаемое: $a$ - пески кварцевые, каолинсодержащие; $\sigma$ - каолины 
Для получения более высоких марок стекольных песков необходимо обогащение исходного сырья. Основной вредной примесью является железо, входящее в состав различных минералов. Основная масса кварца представлена полупрозрачными чистыми зернами (рис. 4 a). Некоторые из них ожелезнены

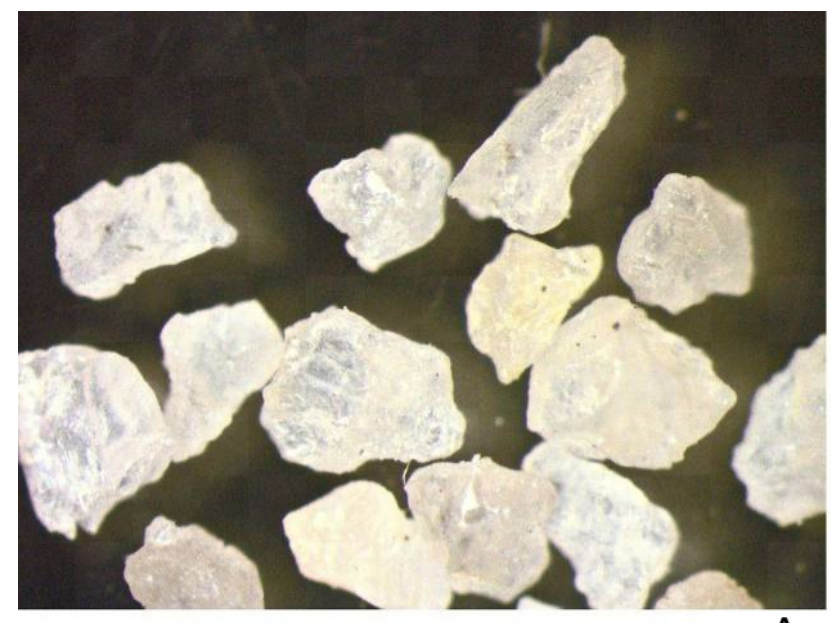

A

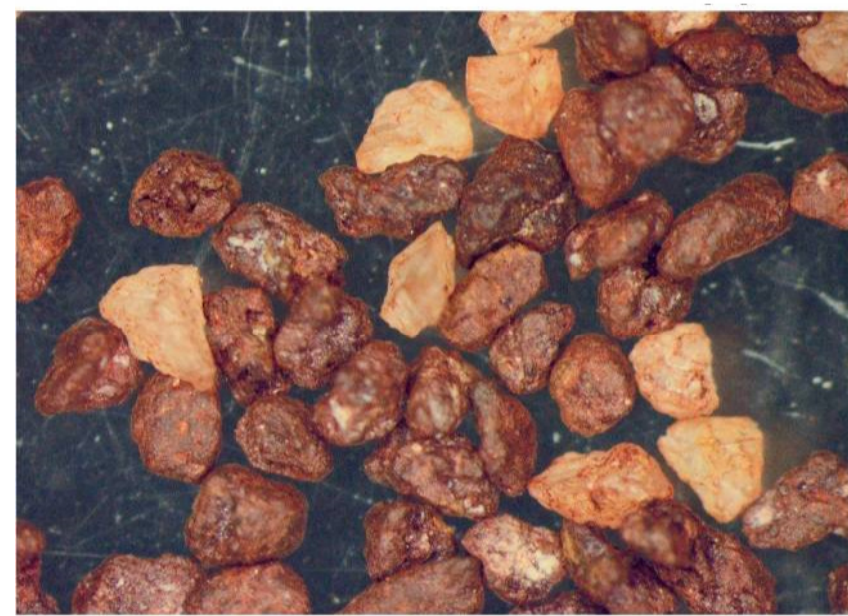

B

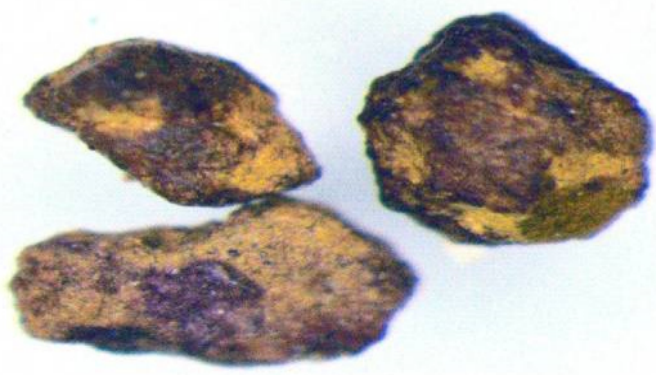

Д (рис. 4 б). В тяжелой фракции присутствуют зерна гематита, пирита, гетита (рис. 4 в-е). По данным рентгеноструктурного анализа обнаруживается лепидокрокит. Знание примесей в минералах железа позволит выбрать оптимальные схемы обогащения кварцевых песков рассматриваемого месторождения.
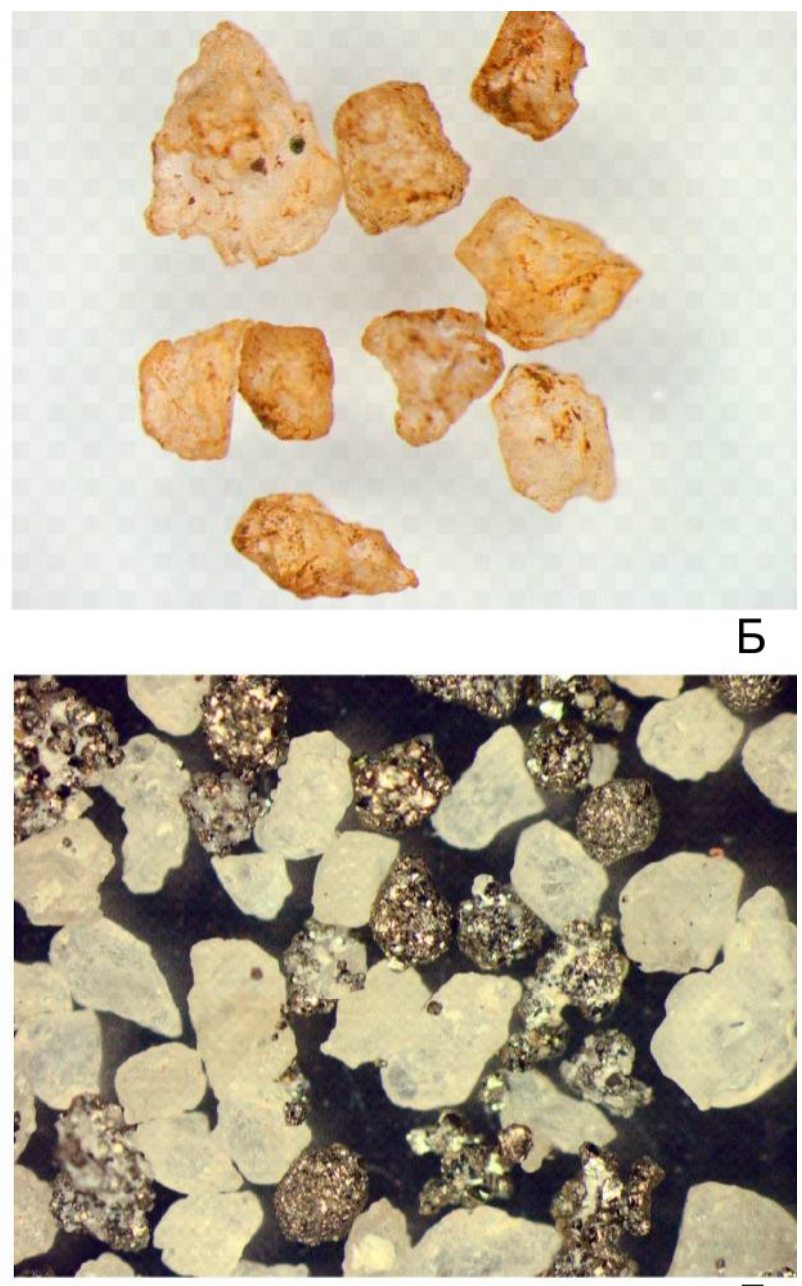

$\Gamma$

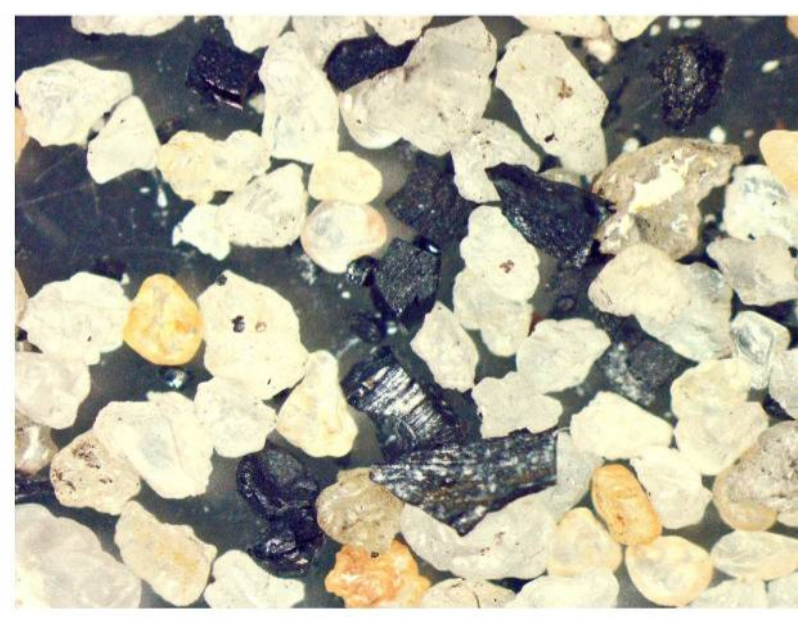

E

Puc. 4. Фото зерен кварца: $a$ - чистых, $\sigma$ - ожелезненных; содержащих: $в$ - гематит, 2 - пирит, $\partial$ - гетит, $e$-УРО. 
Оиенка основных параметров качества обогащенных песков в качестве строчтельного сырья [7]

Согласно ГОСТ 8736-2014 [7] строительные пески подразделяются на два класса - I и II. Классификация осуществляется в зависимости от зернового состава (по модулю крупности), остатке песка на сите №063, содержания пылеватых и глинистых частиц, и глины в комках. При обогащении глинистая фракция удаляется.
Обогащенные пески блока $\mathrm{C}_{2}$-І относятся к мелким (модуль крупности (МК) - 1,95), пески всех остальных блоков - к средним (МК - 2,0-2,5). Полный остаток на сите с сеткой 0,063 мм колеблется от $30,92 \%$ до $45,45 \%$ (таблица 2), что соответствует требованиям ГОСТ 8736-2014 [7]. По содержанию зерен размером менее 0,16 мм пески относятся ко II классу. В средних песках I класса частиц данной размерности должно быть не более $5 \%$.

Таблица 2

Средний гранулярный состав песков участка «Козынка»

\begin{tabular}{|c|c|c|c|c|c|c|c|c|c|c|}
\hline \multirow{2}{*}{ Блоки } & \multicolumn{7}{|c|}{$\begin{array}{l}\text { Остатки на ситах } \\
\text { от-до (среднее) }\end{array}$} & \multirow{2}{*}{$\begin{array}{c}\text { Модуль } \\
\text { крупности }\end{array}$} & \multirow{2}{*}{$\begin{array}{c}\text { Полный } \\
\text { остаток } \\
\text { на сите № } \\
063\end{array}$} & \multirow{2}{*}{$\begin{array}{c}\text { Содержание } \\
\text { зерен крупно- } \\
\text { стью, <0,16 мм }\end{array}$} \\
\hline & $10-5$ & $\begin{array}{l}5,0- \\
2,5\end{array}$ & $\begin{array}{l}2,5- \\
1,25\end{array}$ & $\begin{array}{c}1,25- \\
0,63\end{array}$ & $\begin{array}{l}0,63- \\
0,315\end{array}$ & $\begin{array}{c}0,315- \\
0,16 \\
\end{array}$ & $\begin{array}{c}0,16- \\
0,05\end{array}$ & & & \\
\hline $\mathrm{C}_{1}-\mathrm{I}$ & 0 & $\begin{array}{c}0,3- \\
3,86 \\
(1,75) \\
\end{array}$ & $\begin{array}{l}3,84- \\
18,50 \\
(9,04) \\
\end{array}$ & $\begin{array}{c}12,18- \\
29,39 \\
(19,23) \\
\end{array}$ & $\begin{array}{c}24,94- \\
50,8 \\
(36,35) \\
\end{array}$ & $\begin{array}{c}10,43- \\
42,0 \\
(26,61) \\
\end{array}$ & $\begin{array}{l}1,33- \\
21,62 \\
(7,02) \\
\end{array}$ & 2,06 & 30,92 & 7,02 \\
\hline $\mathrm{C}_{1}$-III & $\begin{array}{l}0-1,8 \\
(0,08)\end{array}$ & $\begin{array}{l}0,1- \\
8,45 \\
(1,8) \\
\end{array}$ & $\begin{array}{c}2,3- \\
29,54 \\
(10,93) \\
\end{array}$ & $\begin{array}{c}9,76- \\
39,88 \\
(21,20) \\
\end{array}$ & $\begin{array}{c}21,47- \\
45,5 \\
(32,50) \\
\end{array}$ & $\begin{array}{l}6,47- \\
50,56 \\
(27,33) \\
\end{array}$ & $\begin{array}{c}0,37- \\
9,66 \\
(6,17) \\
\end{array}$ & 2,05 & 32,51 & 6,34 \\
\hline $\mathrm{C}_{1}-\mathrm{V}$ & $\begin{array}{c}0- \\
14,39 \\
(0,89) \\
\end{array}$ & $\begin{array}{l}0,39- \\
13,82 \\
(2,96) \\
\end{array}$ & $\begin{array}{c}5,59- \\
20,91 \\
(11,48) \\
\end{array}$ & $\begin{array}{c}19,14- \\
37,65 \\
(23,41) \\
\end{array}$ & $\begin{array}{c}22,62- \\
43,92 \\
(32,62) \\
\end{array}$ & $\begin{array}{c}12,83- \\
32,95 \\
(23,42) \\
\end{array}$ & $\begin{array}{c}1,37- \\
9,98 \\
(5,23) \\
\end{array}$ & 2,26 & 38,68 & 5,21 \\
\hline $\begin{array}{l}\mathrm{C}_{1^{-}} \\
\mathrm{VII}\end{array}$ & $\begin{array}{c}0- \\
14,37 \\
(1,15) \\
\end{array}$ & $\begin{array}{l}0,26- \\
14,61 \\
(4,01) \\
\end{array}$ & $\begin{array}{c}1,9- \\
27,73 \\
(13,47) \\
\end{array}$ & $\begin{array}{c}8,45- \\
37,65 \\
(22,13) \\
\end{array}$ & $\begin{array}{c}22,41- \\
33,8 \\
(28,39) \\
\end{array}$ & $\begin{array}{c}9,34- \\
53,68 \\
(24,56) \\
\end{array}$ & $\begin{array}{l}1,37- \\
13,46 \\
(6,3) \\
\end{array}$ & 2,43 & 45,45 & 6,63 \\
\hline $\mathrm{C}_{2}-\mathrm{I}$ & 0 & $\begin{array}{c}0,71- \\
1,42 \\
(1,05)\end{array}$ & $\begin{array}{c}2,97- \\
9,16 \\
(5,47)\end{array}$ & $\begin{array}{c}9,5- \\
19,54 \\
(15,96)\end{array}$ & $\begin{array}{c}23,81- \\
41,44 \\
(33,83)\end{array}$ & $\begin{array}{c}28,15- \\
43,63 \\
(34,38)\end{array}$ & $\begin{array}{l}4,75- \\
23,02 \\
(9,32)\end{array}$ & 1,95 & 27,84 & 6,91 \\
\hline $\mathrm{C}_{2}$-III & 0 & $\begin{array}{l}0,67- \\
30,93 \\
(6,79) \\
\end{array}$ & $\begin{array}{l}5,39- \\
10,88 \\
(8,38) \\
\end{array}$ & $\begin{array}{c}9,30- \\
27,02 \\
(18,31) \\
\end{array}$ & $\begin{array}{c}17,76- \\
38,53 \\
(29,96) \\
\end{array}$ & $\begin{array}{c}20,56- \\
37,79 \\
(26,05) \\
\end{array}$ & $\begin{array}{c}5,19- \\
23,95 \\
(10,51) \\
\end{array}$ & 2,05 & 32,68 & 7,26 \\
\hline $\mathrm{C}_{2}-\mathrm{V}$ & 0 & $\begin{array}{c}0,64- \\
2,24 \\
(1,58)\end{array}$ & $\begin{array}{l}6,13- \\
10,54 \\
(8,24)\end{array}$ & $\begin{array}{c}18,66- \\
22,18 \\
(20,16)\end{array}$ & $\begin{array}{c}31,79- \\
35,99 \\
(33,75)\end{array}$ & $\begin{array}{c}24,24- \\
31,03 \\
(28,46)\end{array}$ & $\begin{array}{c}6,72- \\
9,76 \\
(7,82)\end{array}$ & 2,15 & 35,97 & 6,36 \\
\hline $\begin{array}{l}\mathrm{C}_{2^{-}} \\
\text {VII }\end{array}$ & 0 & $\begin{array}{l}1,34- \\
19,28 \\
(6,83) \\
\end{array}$ & $\begin{array}{l}5,82- \\
11,94 \\
(8,35) \\
\end{array}$ & $\begin{array}{c}12,01- \\
22,25 \\
(15,33) \\
\end{array}$ & $\begin{array}{c}21,74- \\
36,20 \\
(26,08) \\
\end{array}$ & $\begin{array}{c}22,55- \\
39,78 \\
(31,20) \\
\end{array}$ & $\begin{array}{c}4,60- \\
22,19 \\
(12,21) \\
\end{array}$ & 2,01 & 32,00 & 8,81 \\
\hline
\end{tabular}

Оценка основных параметров качества обогащенных песков в качестве формовочного сырья [8]

Обогащенные пески блоков $\mathrm{C}_{1}$-I, $\mathrm{C}_{1}$-III, $\mathrm{C}_{1}-\mathrm{V}, \mathrm{C}_{1}$ VII, $\mathrm{C}_{2}$-I, $\mathrm{C}_{2}$-III, $\mathrm{C}_{2}-\mathrm{V}, \mathrm{C}_{2}$-VII были оценены по ГОСТ 2138-91 в качестве формовочных. Пески содержат менее $0,2 \%$ глинистой составляющей, поэтому относятся к 1 группе. Средневзвешенная массовая доля $\mathrm{SiO}_{2}$ составляет для блока $\mathrm{C}_{1}-\mathrm{I}-98,79 \%, \mathrm{C}_{1}$-III $98,93 \%, \mathrm{C}_{1}-\mathrm{V}-98,67 \%, \mathrm{C}_{1}-\mathrm{VII}-98,52 \%, \mathrm{C}_{2}-\mathrm{I}-98,89$ $\%, \mathrm{C}_{2}$-III - 98,94\%, $\mathrm{C}_{2}-\mathrm{V}-98,81 \%, \mathrm{C}_{2}$-VII - 98,41\%, что позволяет отнести пески к группе $\mathrm{K}_{2}$. Средневзвешенный коэффициент однородности составляет 30,60-39,60 (группа $\mathrm{O}_{5}$ ). Средневзвешенный средний размер зерен для блока $\mathrm{C}_{1}$-I $-0,46 \mathrm{мм}, \mathrm{C}_{1}$-III $0,46 \mathrm{~mm}, \mathrm{C}_{1}-\mathrm{V}-0,54 \mathrm{~mm}, \mathrm{C}_{1}$-VII $-0,53 \mathrm{~mm}, \mathrm{C}_{2}-\mathrm{I}-$ 0,43 мм, $\mathrm{C}_{2}$-III - 0,44 мм, $\mathrm{C}_{2}-\mathrm{V}-0,49 \mathrm{мм}, \mathrm{C}_{2}$-VII 0,02 мм. По этому показателю пески блока $\mathrm{C}_{2}$-VII относятся к группе О1, всех остальных - О3. Соответственно, марка формовочных песков для блока $\mathrm{C}_{2}$-VII $-1 \mathrm{~K}_{2} \mathrm{O}_{5} \mathrm{O} 1$, всех остальных $-1 \mathrm{~K}_{2} \mathrm{O}_{5} \mathrm{O} 3$.
Оиенка основных параметров качества обогащенных песков в качестве стекольного сырья [6]

Для исследования были представлены пять рядовых проб кварцевого песка, из которых методом усреднения была составлена одна объединенная проба для проведения аналитико-технологических исследований с целью определения возможности использования в стекольной промышленности. Исследования проводились в лаборатории «ЦНИИгеонеруд».

Программа испытаний объединенной пробы песка включала пробоподготовку, и определение физикохимических показателей: зернового состава, содержания пылевидных и глинистых частиц, минералогопетрографического и химического составов, а также проведение обогатительных операций (промывку, классификацию, оттирку, ультразвуковое воздействие, электромагнитную сепарацию).

По остатку на сите с сеткой 0,8 мм исследуемые исходные $(19,63 \%)$ и отмытые пески $(22,14 \%)$ не 
соответствует нормам ГОСТ 22551-77 (в необогащенном песке должно быть не более $5 \%$, в обогащенном не более $0,5 \%$ ) и, поэтому, не могут быть использованы в стекловарении без классификации. Содержание в песке пылевидных и глинистых частиц - 7,02\%.

Исследуемый песок представлен угловатым разнозернистым кварцем. В виде примесей встречаются единичные зерна пирита, полевого шпата и гидрооксидов железа. Кроме того, кварц часто содержит рудные включения внутри зерна и оставшиеся после промывки сцементированные каолином кварцевые зерна.

Кварцевый песок по содержанию оксидов железа, кремния и алюминия соответствует марке Т [6]. Для улучшения марки песка использовались следующие методы обогащения: промывка, классификация, оттирка, ультразвуковое воздействие, электромагнитная сепарация. Эти методы способствуют избавлению от вредных примесей - глинистой составляющей, каолинового цемента на кварцевых зернах и зерен минеральных примесей, содержащих железо.

На стадии промывки происходит удаление глинистой фракции. Выход глинистого шлама составил 7,0 \%.

Стадия оттирки и ультразвукового воздействия необходима из-за присутствия в песке зерен кварца разной крупности, сцементированных каолином, и зерен, содержащих железо в виде тонких корочек и налетов. Для улучшения качества оттирки пленки с поверхности зерен кварца, добавлялась сода. Время оттирки составляло 20 минут. Выход оттертого шлама составил 0,4\%.

На стадии классификации осуществляется выравнивания однородности зернового состава кварцевых зерен, удаления из песка части тяжелых минералов и как подготовительная стадия для электромагнитной сепарации проводилась классификация с получением классов крупности менее 0,8 мм и более 0,1 мм. Выход отсеянных зерен составил $23,9 \%$.

Применение электромагнитной сепарации обусловлено присутствием в песках минералов, обладающих определенным значением магнитной восприимчивости. Для этого промежуточная фракция 0,8+0,1 мм рассеивались на классы крупности: $+0,63$; $+0,4 ;+0,315 ;+0,2 ;+0,16$ и +0,1 мм. Каждый класс крупности сепарировался отдельно на электромагнитном сепараторе. Выход магнитной фракции при сепарации составил $1,05 \%$.

Анализ результатов обогащения, представленных в таблице 3 показывает, что использованные методы обогащения неравномерно снижают содержание основной окрашивающей стекло примеси - оксида железа.

Так после промывки из марки Т получен концентрат марки ПС-250, пригодный для производства пеностекла, стекловолокна для строительных целей, консервной тары и бутылок из полубелого стекла, изоляторов, труб, аккумуляторных банок.

После классификации промытого песка вместо марки ПС-250 получен концентрат марки Б-100-1, пригодный для производства силикат-глыбы, стекловолокна для электротехники, оконного стекла, изоляторов, труб, консервной тары и бутылок из полубелого стекла.

Использование методов оттирки и низкочастотного ультразвукового воздействия хоть и позволило снизить содержание оксида алюминия и повысить содержание оксида кремния, однако не повлияло на конечную марку концентрата. После заключительной стадии - электромагнитной сепарации получен концентрат марки С-070-1. Преимущественная область применений данного концентрата - производство оконного и технического стекла, стеклопрофилита, стеклоблоков, белой консервной тары и бутылок, проката, стекловолокна для электротехники.

Таблица 3

Результать влияния обогащения на химический состав и марку кварцевого песка

\begin{tabular}{|l|c|c|c|c|c|}
\hline \multicolumn{1}{|c|}{ Стадия обогащения } & \multicolumn{5}{c|}{ Содержание, $\%$} \\
\cline { 2 - 7 } & $\mathrm{SiO}_{2}$ & $\mathrm{TiO}_{2}$ & $\mathrm{Al}_{2} \mathrm{O}_{3}$ & $\mathrm{Fe}_{2} \mathrm{O}_{3}$ & $\mathrm{Mapка}$ \\
\hline Песок исходный (ИС) & 95,85 & 0,11 & 1,78 & 0,27 & $\mathrm{~T}$ \\
\hline Песок отмытый (ОМ) & 98,72 & 0,05 & 0,40 & 0,17 & ПС-250 \\
\hline Песок отмытый и классифицированный (ОМК) & 99,27 & 0,04 & 0,21 & 0,08 & Б- $100-1$ \\
\hline Песок отмытый, классифицированный и оттертый (ОМКОТ) & 99,40 & 0,05 & 0,13 & 0,08 & Б- $100-1$ \\
\hline $\begin{array}{l}\text { Песок отмытый, классифицированный, оттертый и } \\
\text { обработанный ультразвуком (ОМКОТУ) }\end{array}$ & 99,51 & 0,04 & 0,14 & 0,08 & Б- $100-1$ \\
\hline $\begin{array}{l}\text { Песок отмытый и классифицированный, обработанный } \\
\text { ультразвуком и обогащенный электромагнитной сепарацией } \\
\text { (ОМКОТУМС) }\end{array}$ & 99,52 & 0,01 & 0,13 & 0,06 & С-070-1 \\
\hline
\end{tabular}

Каолин обогащченный (фракиция < 63 мкм) из квариевых каолинитсодержащих песков

Каолин является еще одним типом полезных ископаемых, попутным в соответствующих горизонтах песков. Запасы каолина в 4-х горизонтах каолинитсодержащих песков составляют 13,6 \% от общих запасов каолина категории $\mathrm{C}_{1}+\mathrm{C}_{2}$ (см. табл. 1). Средневзвешенное значение по блокам выхода обогащенного каолина (фракция < 63 мкм) значительно колеблется, возрастая снизу вверх, от 4,25-4,81\% (блоки $\mathrm{C}_{1}-\mathrm{I}, \mathrm{C}_{2}$ I) до 12,41-15,61 \% (блоки $\mathrm{C}_{1}$-VII, $\mathrm{C}_{2}$-VII).

Качество каолина этого типа полезных ископаемых заметно выше, чем качество каолина в собственно каолинитовых горизонтах. Это проявляется в более благоприятном химическом составе (более высокое содержание $\mathrm{Al}_{2} \mathrm{O}_{3}$, и низкое - красящих оксидов). Во всех 8-ми блоках $\left(\mathrm{C}_{1}\right.$-I, $\mathrm{C}_{2}$-I, $\mathrm{C}_{1}$-III, $\mathrm{C}_{2}$-III, $\mathrm{C}_{1}-\mathrm{V}, \mathrm{C}_{2}-\mathrm{V}$, $\mathrm{C}_{1}$-VII, $\mathrm{C}_{2}$-VII) средневзвешенное содержание $\mathrm{TiO}_{2}$ 
(0,97-1,15\%) даже удовлетворяет требованиям ГОСТ 21286-82 [9], предъявляемым к изделиям санитарностроительной керамики марки КС-1 (норма $\leq 1,2 \%)$.

Средневзвешенное содержание по блокам $\mathrm{Al}_{2} \mathrm{O}_{3}$ поднимается до 32,15-34,32 \%. В трех блоках $\left(\mathrm{C}_{1}-\mathrm{I}\right.$, $\left.\mathrm{C}_{2}-\mathrm{I}, \mathrm{C}_{2}-\mathrm{V}\right)$ содержание глинозема более $34 \%$ и немногим не соответствует марке КС-1 санитарностроительной керамики (норма $\geq 35 \%$ ). Средневзвешенное содержание по блокам $\mathrm{Fe}_{2} \mathrm{O}_{3}-1,49-1,94 \%$.

Оценивая изменение качества по площади и разрезу, необходимо отметить, что наилучшие показатели химического состава в блоке $\mathrm{C}_{2}-\mathrm{V}$. В нем содержание $\mathrm{Al}_{2} \mathrm{O}_{3}$ - максимальное $(34,32 \%)$ среди всех блоков; а $\mathrm{Fe}_{2} \mathrm{O}_{3}(1,49 \%)$ и $\mathrm{TiO}_{2}(0,97 \%)$ - минимальное.

По классификации сырья для керамической промышленности [10] каолин из каолинитсодержащих песков относится к группам основных; огнеупорных $\left(1635-1690^{\circ} \mathrm{C}\right)$; со средним содержанием красящих оксидов; низко- и среднедисперсных (содержание по блокам фракции <1 мкм 39,02-47,67 \%); умереннопластичных (с числом пластичности 10,46-11,64); с умеренной механической прочностью на изгиб $(3,70$ 4,67 МПа).

Особенности химического состава каолинов и их физико-механические показатели позволяют использовать их в качестве формовочных [11] и в качестве огнеупорных глин. Средневзвешенное значение по блокам предела прочности при сжатии во влажном $(2,83-3,34$ Па) и сухом состоянии $(18,51-25,11)$ соответствует маркам малопрочных мало- и среднесвязующих формовочных огнеупорных глин (M3, M2).

\section{Выводы}

Таким образом, исследования показали, что обогащенные пески участка «Козынка» могут использоваться в качестве строительных, формовочных и стекольных. Строительные пески отвечают II классу, лишь немногим не соответствуя I классу по содержанию зерен менее 0,16 мм. Формовочные пески, преимущественно, марки $1 \mathrm{~K}_{2} \mathrm{O}_{5} \mathrm{O} 3$ с невысоким коэффициентом однородности и средним размером зерна свыше 0,28 мм.

Исходные обогащенные пески соответствуют марке T, пригодной для изготовления бутылочного зеленого стекла. После дальнейшего обогащения получен концентрат марки Б-100-1, пригодный для производства силикат-глыбы, стекловолокна для электротех-

Воронежский государственный университет Мануковский Сергей Викторович, к.г.-м.н., старший научный сотрудник НИИ Геологии ВГУ

E-mail: manukovsky@inbox.ru; Тел.: 8 (473) 222-65-12

Крайнов Алексей Владимирович, к.г.-м.н., научный сотрудник НИИ Геологии

E-mail: aleksey_vsu_geo@mail.ru; Тел.: 8-952-548-47-72

Корабельников Николай Анатольевич, преподаватель кафедры гидрогеологии, инженерной геологии и геоэкологии E-mail: gidrogeol@mail.ru; Тел.: 8(473)220-89-80

Милаш Алексей Васильевич, ведущий инженер НИИ Геолоzuи. E-mail: pirit86@yandex.ru; Тел.: 8-903-030-51-47 ники, оконного стекла, изоляторов, труб, консервной тары и бутылок из полубелого стекла и концентрат марки C-070-1. для производства оконного и технического стекла, стеклопрофилита, стеклоблоков, белой консервной тары и бутылок, проката, стекловолокна для электротехники.

Обогащенный каолин из глинистой составляющей всех песчаных горизонтов (I, III, V, VII) может быть использован в качестве формовочных и огнеупорных глин. Огнеупорные глины всех 8 блоков соответствуют сортам Латненского месторождения ЛТ-3Ж, ЛТКЖ, ЛТ-У1. Кроме этих марок, в блоках $\mathrm{C}_{1}$-III и $\mathrm{C}_{2}-\mathrm{V}$ качество сырья повышается до марки ЛТ-3С [12].

Исследование выполнено при финансовой поддержке РФФИ в рамках научного проекта № 18-35-00115

\section{ЛИТЕРАТУРА}

1. Тектоника восточной части Воронежского кристаллического массива и его осадочного чехла / Г. И. Раскатов [и др.]. // Воронеж: Изд-во ВГУ, 1976. - 120 с.

2. Савко, А. Д. Литология и полезные ископаемые мамонской песчано-каолиновой толщи Воронежской антеклизы / А. Д. Савко, С. В. Мануковский, Л. Т. Шевырев // Труды научно-исследовательского института геологии Воронеж. гос. ун-та. - Вып. 53. - 2008. - 112 с.

3. Окороков, В. А. Литология фаменских отложений Воронежской антеклизы / В. А. Окороков, А. Д. Савко // Воронеж: Воронежский госуниверситет, 1998. - 124 с.

4. Савко, А. Д. Эпохи корообразования в истории Воронежской антеклизы / А. Д. Савко. - Воронеж : Изд-во Воронежс. ун-та, 1979. - 119 с.

5. ГОСТ 21286-82. Каолин обогащенный для керамических изделий. Технические условия. - М., 1982. - 7 с.

6. ГОСТ 22551-77. Песок кварцевый, молотые песчаник, кварцит и жильный кварц для стекольной промышленности. Технические условия. - М., 1977. - 11 с.

7. ГОСТ 8736-2014. Песок для строительных работ. Технические условия. - М., 2015. - 12 с.

8. ГОСТ 2138-91. Пески формовочные. Общие технические условия. - М., 1992. - 6 с.

9. ГОСТ 21286-82. Каолин обогащенный для керамических изделий. Технические условия. - М., 1982. - 6 с.

10. ГОСТ 9169-75. Сырье глинистое для керамической промышленности. Классификация. - М., 1975. - 13 с.

11. ГОСТ 3226-93. Глины формовочные огнеупорные. Общие технические условия. - Минск, 1994. - 9 с.

12. ТУ 1512-003-10612023-15. Глина огнеупорная Латненского месторождения. - Воронеж, 2015. - 3 с.

Voronezh State University

Manukovsky S. V., Ph.D in Geology, leading scientific associate of Scientific Research Institute of Geology.

E-mail: manukovsky@inbox.ru; Тел.: 8 (473) 222-65-12

Krainov A. V., Ph.D in Geology, the master engineer of Scientific Research Institute of Geology

E-mail: aleksey_vsu_geo@mail.ru; Тел.: 8-952-548-47-72

Korabel'nikov N. A., Assistant of chair of Hydrogeology, engineering geology and geoecology of Voronezh State University.E-mail: gidrogeol@mail.ru; Tel.: 8(473)220-89-80

Milash A. V., the lead engineer of Scientific Research Institute of Geology.E-mail: pirit86@yandex.ru; Tel.: 8-903-030-51-47 